István Fodor

Anna Dunay

László Ózsvári

\title{
3.3. ECONOMIC IMPACTS OF MASTITIS AND REPRODUCTIVE DISORDERS IN THE HUNGARIAN DAIRY HERDS
}

\begin{abstract}
Summary
The sharp competition among dairy herds in the EU caused the recognition in herd managers that the main sources of losses related to herd health should be discovered. The object of this study was to quantify average annual losses due to mastitis and reproductive disorders in dairy herds. The study included 8 Hungarian herds with 6,825 Holstein-Friesian cows, altogether. The results showed that the decrease in milk production of cows suffering from subclinical mastitis means 58.9 EUR loss per cow per year. The amount of discarded milk, early culling due to mastitis and the drug costs were responsible for 49.5 EUR, 39.1 EUR and 12.9 EUR extra costs, respectively. Therefore, the average annual loss due to mastitis was 160.4 EUR per cow in 2011. Milk losses, early culling and drug costs caused 67.6\% (108.4 EUR), $24.4 \%$ (39.1 EUR) and 8\% (12.9 EUR) of the total amount of losses, respectively. Annual loss of income related to reproductive disorders exceeded 227 EUR. Increased calving interval caused the majority of this loss $(70.9 \%, 161$ EUR). Premature disposal owing to reproductive disorders also had large economic impact, causing 13.4\% (30.5 EUR) of the total loss. Treatment cost brought about 16.9 EUR (7.5\%), while increased number of services per cow was responsible for $8 \%$ (18.7 EUR) of the total expenditures.
\end{abstract}

Keywords: economic losses, mastitis failure, reproductive failure, dairy herd

\section{Introduction}

The competition among dairy producers is getting even sharper nowadays. In this challenging situation Hungarian dairies are only able to survive by continuously increasing the efficiency and thereby the profitability of their production (see also Illés, 1998). The level of animal health is a major influencing factor of the profitability on dairy farms, thus, it is strongly advised to explore herd-level diseases causing the greatest economic losses. Having quantified economic losses cost-benefit analysis of new management implementations becomes possible. Studies and surveys of the recent decades show that mastitis and reproductive disorders are responsible for the greatest herd-level losses.

\section{Economics of mastitis}

Mastitis is the most common and most costly disease on the dairy farms of developed countries (Seegers et al., 2003). Several risk factors affect its occurrence, thus making mastitis prevention a difficult task. In addition, numerous production parameters are influenced by this disease, causing huge herd-level losses, both 
Fodor, I. - Dunay, A. - Ózsvári, L.

decreased income (hidden loss) and increased direct cost (Huijps et al., 2010; Leblanc et al., 2006; Østergaard et al., 2005; Seegers et al., 2003, Valeeva et al., 2007).

The health status of the udder is mostly measured by somatic cell counts (the number of somatic cells per millilitre milk; SCC/ml), which - according to recent studies - remains under $50,000 \mathrm{SCC} / \mathrm{ml}$ if the mammary gland is healthy. When the udder becomes diseased, the SCC increases (Hagnestam-Nielsen et al., 2009; Halasa et al., 2009).

Basically, we have to make a distinction between clinical and subclinical mastitis. In the clinical cases, we can find changes on the udder and in the milk during physical examination, while the subclinical cases are indicated only by the elevated SCC of the milk. It has to be emphasized, that according to the surveys made so far, the economic impact of the subclinical form is much larger than the losses caused by clinical mastitis. In practice, the clinical form is identified in the milking parlours, however, the subclinical form, which is more difficult to detect, is diagnosed with either California Mastitis Test (CMT) or in laboratories with precise cell counter devices (Rafai et al., 2003; Wolfová et al., 2006).

Most authors classify mastitis pathogens into infectious pathogens and environmental pathogens. Infectious pathogens are able to spread from one cow to the other within the herd, in which milking hygiene has an important role. Environmental pathogens originate from the faecal contaminated keeping place of the animals, threatening udder health during lactation as well as during the dry period. It has to be mentioned that some pathogens are able to spread both ways (Rafai et al., 2003).

On the modern large-scale dairy cattle farms, Staphylococcus aureus causes the greatest economic losses among the infectious pathogens, which is widespread also in Hungary. Coliform bacteria are one the most important environmental pathogens; according to the survey of Ózsvári (2004) they cause 160 EUR loss per infected cow annually. Sources of herd-level losses due to mastitis are shown in Figure 1.

Figure 1. Sources of herd-level losses due to mastitis (Ózsvári, 2004)

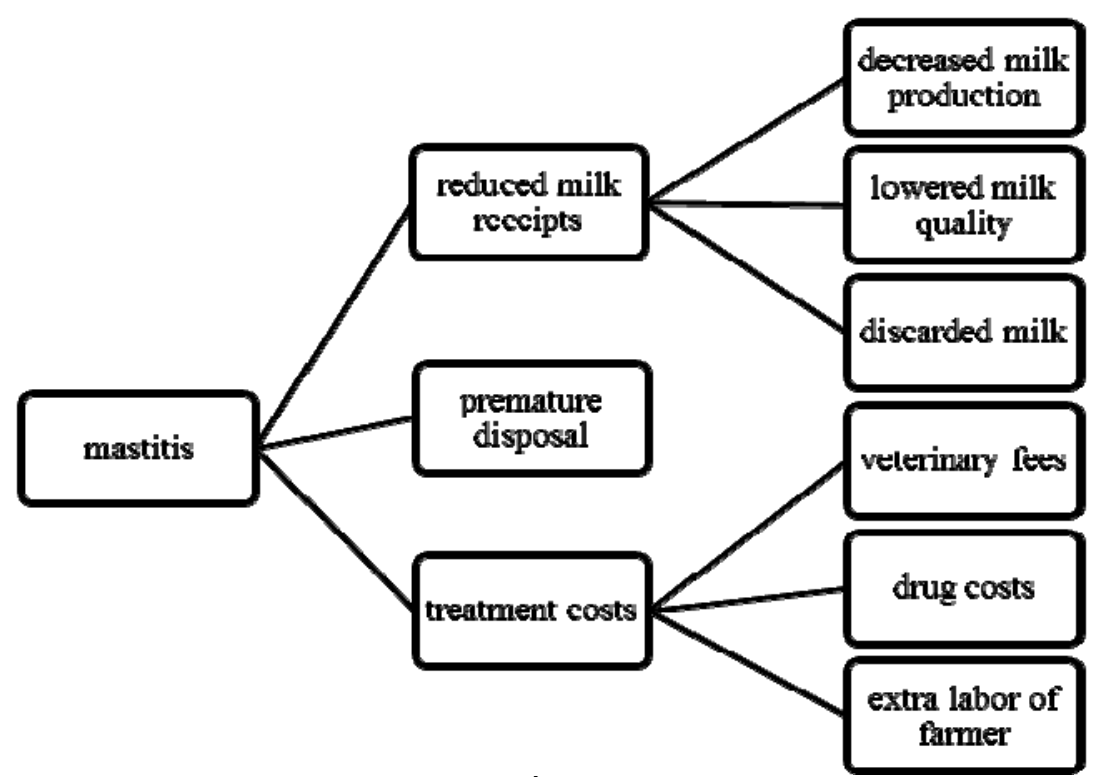

Source: Ózsvári, 2004 


\section{Reduced milk receipts}

Reduced milk receipts make two-third of the total losses related to mastitis (Ózsvári et al., 2001; Ózsvári et al. 2003a; Wolfová et al., 2006). This source of loss originates from decreased milk yield, lowered milk quality and the amount of discarded milk, of which decreased milk production plays the most important role (Table 1).

Table 1. Annual milk yield decrease per cow related to mastitis

\begin{tabular}{|l|c|}
\hline \multicolumn{1}{|c|}{ Study } & Milk yield decrease (kg/cow/year) \\
\hline Blosser, 1979 & 386 \\
\hline Mcnab- Meek, 1991 & 170 \\
\hline Ózsvári, 2004 & 211 \\
\hline Østergaard et al., 2005 & 385 \\
\hline
\end{tabular}

Source: own construction

The more severe the mastitis, the more the milk is lost. Severity of mastitis can be expressed by the elevation of SCC. According to more recent studies the udder has to be considered healthy if the somatic cell count of the produced milk is under 50,000 $\mathrm{SCC} / \mathrm{ml}$, however, in our present study we used $250,000 \mathrm{SCC} / \mathrm{ml}$ as a threshold to regard cows as being diseased with subclinical mastitis, because above this threshold we can find mastitis pathogens in almost all cases (Ózsvári, 2004). Daily milk production loss depends not only on the SCC of the milk, but also on the number of lactation and days in milk (Figure 2).

Figure 2. Relationship among SCC, stage of lactation and milk production

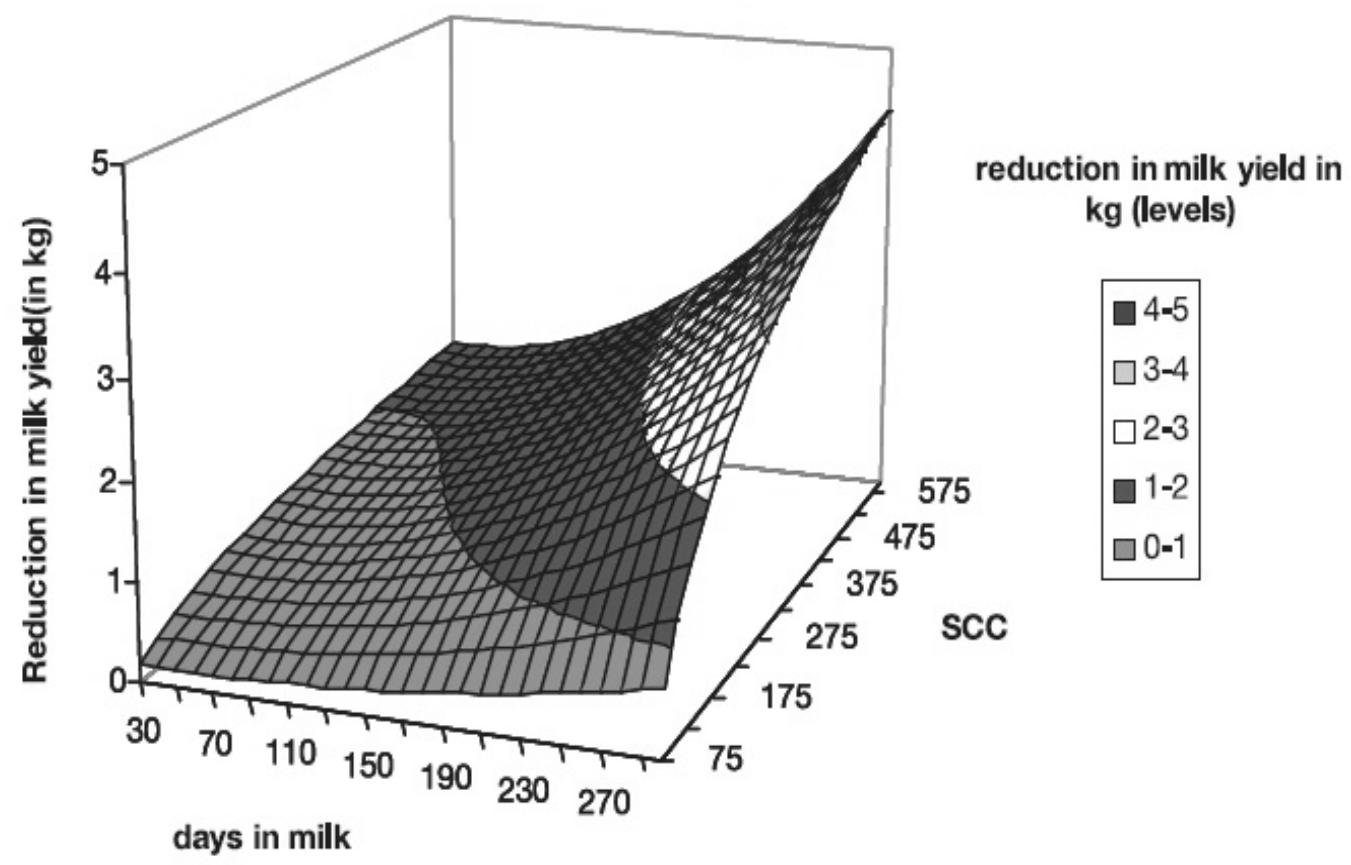

Source: Seegers et al., 2003 
Fodor, I. - Dunay, A. - Ózsvári, L.

The largest milk production loss occurs in cows in their second or later lactation and in the later stages of lactation, that is why management measurements against subclinical mastitis should mainly focus on these animals. According to the study of Hagnestam-Nielsen et al. (2009), the milk yield decrease above 500,000 SCC/ml is 3$9 \%$ in cows in their first lactation and may reach $18 \%$ in cows with more lactations! In addition, older cows represent a higher proportion in the herd, thus making them responsible for the majority of the herd-level milk production losses.

Mastitis cases are usually treated with antibiotics, but milk for human consumption must not contain antibiotic residues, so the milk produced during the withdrawal time of the medication is discarded or fed with the calves. In the second case the farm can reduce its production costs by spending less on milk powder, however, the chance for infectious diseases to appear (especially Johne's disease and salmonellosis) is higher (Blosser, 1979; Mcnab- Meek, 1991; Swinkels et al., 2005). Different studies showed different financial losses related to discarded milk (Table 2).

Table 2. Losses related to discarded milk

\begin{tabular}{|l|c|}
\hline \multicolumn{1}{|c|}{ Study } & Loss (USD/cow/year) \\
\hline Dobbins, 1977 & 7.72 \\
\hline Blosser, 1979 & 12.88 \\
\hline Ózsvári, 2004 & 26.9 \\
\hline Wolfová et al., 2006 & $39^{\mathrm{a}}$ \\
\hline Cha et al., 2011 & $20^{\mathrm{b}}$ \\
\hline a : EUR/cow/year; ${ }^{\mathrm{b}}:$ USD/mastitis case \\
Source: own construction
\end{tabular}

In several countries farmers are encouraged to improve udder health with quality premiums based on milk SCC. In Hungary producers are not permitted to buy milk from the farm above 400,000 SCC/ml (Ózsvári, 2004; Valeeva et al., 2007).

\section{Cost of premature disposal}

Culling of cows can be classified into voluntary and involuntary culling. Voluntary culling means that it is economically not beneficial to keep the cow in the herd anymore because of its low production or unfavourable genetics. If a health problem as a forcing factor leads to the disposal of the animal, it is called involuntary or premature culling. Mastitis is the second most common reason of premature disposal, running up to $5-17 \%$ of the total disposals. The raising cost of heifer for replacement can be reduced by the slaughter value of the culled cow (Ózsvári, 2004; Seegers et al., 2003). If the cow dies there is no salvage value. The mortality rate of mastitis caused by Gram negative pathogens is higher than caused by the Gram positive ones. Hazlett et al. (1984) found Escherichia coli in 74\% of the lethal mastitis cases, while the presence of Klebsiella spp. and Staphylococcus aureus were shown in $8 \%$ of the samples, respectively. 


\section{Cost of mastitis treatment}

This expenditure consists of veterinary fees, drug cost and the cost of the extra labour of the farmer (Ózsvári et al., 2003a). According to the study of Bar et al. (2008), treatment cost could reach $30 \%$ of the total losses related to clinical mastitis cases. Veterinary fees may vary on a wide range; in the study of Wolfová et al. (2006) this cost amounted to $14.73 \mathrm{EUR} / \mathrm{cow} / \mathrm{year}$. On the farms which employ a veterinarian with fix salary (it is widespread in Hungary), this cost factor is not taken into account, because the fee of the vet does not depend on mastitis incidence.

Several mastitis treatment options exist, which differ in antimicrobial spectrum, way of application, duration of the effect, and its cost (Ózsvári et al., 2003b). So when we choose a treatment, it is an economic decision, too. Mostly antibiotics or antibioticNSAID (non-steroidal anti-inflammatory drug) combinations are used to treat the mastitis, however, it may come up that culling is the economically optimal decision instead of treating the animal. According to the study of Wolfová et al. (2006) antibiotics were used in $97 \%$ of the clinical mastitis cases. Treatment costs showed significant differences among farms, because of the following factors: severity of clinical mastitis, average duration of the disease and intensity of the treatment. More intensive treatment led to reduced milk production loss and lower cost of culling, but it was necessarily cost-efficient, too. Table 3 shows drug costs according to Cha et al. (2011) and Wolfová et al. (2006).

Table 3. Drug cost of a clinical mastitis case

\begin{tabular}{|l|c|c|}
\hline \multicolumn{1}{|c|}{ Study } & Drug cost/case & $\begin{array}{c}\text { Drug cost in percentage of } \\
\text { clinical mastitis treatment cost }\end{array}$ \\
\hline \multirow{3}{*}{ Cha et al., 2011 } & $23.50 \mathrm{USD}^{\mathrm{a}}$ & $32^{\mathrm{a}}$ \\
\cline { 2 - 3 } & $15.50 \mathrm{USD}^{\mathrm{b}}$ & $43.7^{\mathrm{b}}$ \\
\cline { 2 - 3 } & $19.50 \mathrm{USD}^{\mathrm{c}}$ & $39.4^{\mathrm{c}}$ \\
\hline Wolfová et al., 2006 & $10.6 \mathrm{EUR}$ & $\mathrm{NDA}$ \\
\hline
\end{tabular}

NDA: No data available

${ }^{\mathrm{a}} \mathrm{Gram}$ positive pathogen; ${ }^{\mathrm{b}} \mathrm{Gram}$ negative pathogen; ${ }^{\mathrm{c}}$ other pathogen

Source: own construction

Mastitis cases mean extra cost on the one hand by extending working hours (if the worker is paid on an hourly basis) and on the other hand the employee has to spend time on treating cows with mastitis instead of doing any other work generating income on the farm. Extra labour consists of discarding the milk, time spent on treatment, cleaning devices used for milking separately and for treatment and time spent on diseased cows. This source of loss is usually not taken into account on farms run by families (Blosser, 1979; Ózsvári et al., 2003a; Steeneveld et al., 2011; Swinkels et al., 2005; Wolfová et al., 2006).

In Table 4, you can see total losses related to mastitis according to different studies. 
Fodor , I. - Dunay, A. - Ózsvári, L.

Table 4. Total annual losses due to mastitis

\begin{tabular}{|l|l|c|c|}
\hline Type of mastitis & \multicolumn{1}{|c|}{ Study } & Loss/cow/year & Currency \\
\hline \multirow{2}{*}{$\begin{array}{l}\text { Clinical and } \\
\text { subclinical }\end{array}$} & Blosser, 1979 & 117.4 & \multirow{2}{*}{ USD } \\
\cline { 2 - 4 } & Ózsvári, 2004 & 105.9 & \\
\hline \multirow{4}{*}{ Clinical } & Seegers et al., 2003 & 119 & GBP \\
\cline { 2 - 4 } & Wolfová et al., 2006 & 65.1 & EUR \\
\cline { 2 - 4 } & Bar et al., 2008 & 71 & USD \\
\hline \multirow{3}{*}{ Subclinical } & Yalcin et al., 1999 & 100 & GBP \\
\cline { 2 - 4 } & Ózsvári, 2004 & 73.5 & USD \\
\hline
\end{tabular}

Source: own construction

\section{Economic aspects of reproductive disorders}

In Hungary the most common reproductive disorders which are responsible for poor reproductive performance, are the ovarium disorders, retained placenta and metritis (Vucseta, 2002). Retained placenta is predisposing cows to metritis and endometritis, but usually it does not increase the chance of culling, only if accompanied with complications. Endometritis and subclinical endometritis decrease pregnancy rate and increase number of days open, causing serious financial losses on the farm. Dairy cow nutrition is also an important factor in optimal reproductive performance, especially in postpartum ovarian function. Inadequate feeding may lead to delayed cycle after calving, meaning more days open, as well (Goshen- Shpigel, 2006; Leblanc, 2008).

Reproductive performance of the cows effect the number of calves sold, premature culling due to reproductive failures, drug costs and the number of inseminations directly, while its most significant indirect effect is influencing milk yield and net milk receipts.

Decreased reproductive performance results in decreased net milk receipts (milk receipts over feed costs), increase of culling due to reproductive disorders, less heifers for replacement, increased semen usage and higher veterinary costs (Meadows et al., 2005; Olynk-Wolf, 2008; Ózsvári, 2004). Sources of herd-level losses due to reproductive failures are shown in Figure 3.

Fertility of dairy cows has been decreasing worldwide. It is often explained with the increasing milk production and - as a result - the altered metabolism and hormonal changes. Low fertility is the number one reason of premature culling in dairy herds and reproductive disorders are one of the most important factors decreasing profitability on modern dairy farms. It means that herd level losses could be reduced significantly through shorter calving interval and smaller culling costs by improving reproductive performance (Meadows et al., 2005; Mee, 2007; Ózsvári and Kerényi, 2004). 
Figure 3. Sources of losses due to reprodutive failures

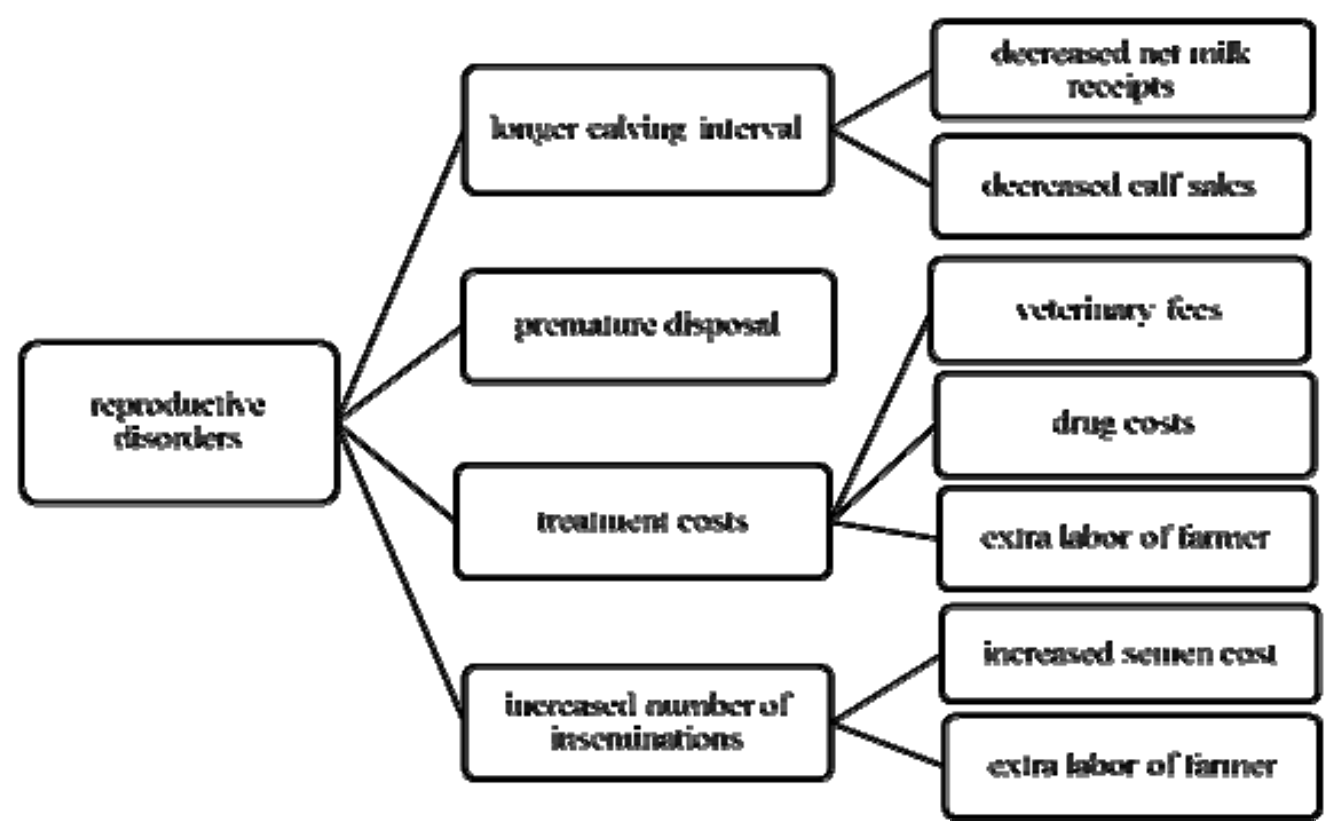

Source: Ózsvári, 2004

According to Inchaisri et al. (2010), the greatest annual losses related to reproductive reasons are caused by the following factors:

1. low conception rate,

2. low heat detection efficiency,

3. length of voluntary waiting period (days from calving to first insemination),

4. postpartum disorders,

5. fetal mortality.

Optimal reproductive potential is a basic interest of dairy farms. Newborn heifers will play an important role later as heifers for replacing culled cows and on the other hand, bull calves sold for slaughtering bring about income for the farm, as well. Financial losses related to abortion are shown in Table 5.

Table 5. Losses due to abortion

\begin{tabular}{l|c|}
\hline Study & Loss (USD/case) \\
\hline Eicker- Fetrow, 2003 & $600-800$ \\
\hline Peter, 2000 & $600-1000$ \\
\hline Pfeiffer et al., 1997 & $624^{\mathrm{a}}$ \\
\hline Thurmond- Picanso, 1990 & 640 \\
\hline Weersink et al., 2002 & $1286^{\mathrm{b}}$ \\
\hline $\begin{array}{l}\text { a }: \text { abortion caused by Neospora caninum; }{ }^{\mathrm{b}} \text { : together with loss from milk yield decrease } \\
\text { Source: De Vries (2006) }\end{array}$
\end{tabular}


Fodor , I. - Dunay, A. - Ózsvári, L.

\section{Longer calving interval and days open}

One of the greatest problems among dairy farmers in Hungary is extended calving interval. The realistic goal would be to reduce calving interval under 400 days, however the Hungarian average was 438 in 2011 (Animal Breeding Performance Testing Ltd., 2011). As the calving interval is increasing, the annual milk yield is decreasing. As a result of premature disposals due to extended calving interval, the possibilities for voluntary culling become even poorer, putting the lid on genetic improvement of the herd (Meadows et al., 2008; Ózsvári et al., 2007).

Several studies have shown that increased milk production results in reduced fertility through the effect of negative energy balance on hormone levels, causing longer calving interval. However length of the Hungarian average calving interval can only partly be explained with this effect, because in countries with much higher milk production (e.g. the Netherlands) calving interval is about 30 days shorter (Inchaisri et al., 2010).

Usually 12 months long calving interval is considered optimal (= 85 days open), which means that the cow produces maximal milk yield and calves born at this interval during her lifetime, but it can be achieved only with strict reproductive culling (Meadows et al., 2005; Ózsvári, 2004). The number of days open increases in line with the extension of calving interval. According to the international literature the optimal length of the service period (days from calving to conception) would be 85 days, but under 100 days is still very good. Table 6 shows the calculated losses due to the nonoptimal calving interval in a Hungarian dairy farm.

Table 6. Calculated losses due to longer calving interval in a Holstein-Friesian Hungarian dairy farm with 1100 cows (EUR/cow/year)

\begin{tabular}{|l|c|c|c|c|c|c|c|}
\hline $\begin{array}{c}\text { Calving interval } \\
\text { (months) }\end{array}$ & $\mathbf{1 1}$ & $\mathbf{1 2}$ & $\mathbf{1 3}$ & $\mathbf{1 4}$ & $\mathbf{1 5}$ & $\mathbf{1 6}$ & $\mathbf{1 7 - 1 8}$ \\
\hline Lactation 1 & 20 & $\mathbf{0}$ & 113 & 232 & 333 & 375 & 454 \\
\hline Lactation 2 & 106 & $\mathbf{0}$ & 316 & 204 & 369 & 343 & 555 \\
\hline Lactation 3 & 8 & 7 & $\mathbf{0}$ & 315 & 234 & 271 & 465 \\
\hline Lactation 4-9 & 176 & $\mathbf{0}$ & 298 & 483 & 624 & 592 & 755 \\
\hline Average cow & 56 & $\mathbf{0}$ & 179 & 265 & 380 & 372 & 498 \\
\hline
\end{tabular}

Note: The calving interval with highest net milk receipts is set at zero. So, in this farm the optimal calving interval is 12 months.

Source: Ózsvári et al., 2007.

\section{Cost of premature disposal}

The most common reason for culling due to a reproduction disorder is the longer calving interval. Replacement heifer is expected to produce higher return than the cow staying in the herd with fertility problems. It is advisable to cull the non-pregnant cow after the $13^{\text {th }}$ month of lactation, because afterwards her keeping in the herd is loss- 
making (De Vries, 2006). Premature disposals due to infertility account for $20-40 \%$ of the total disposals (Meadows et al., 2005), causing 60.4 USD loss per cow annually in Hungary (Ózsvári, 2004).

\section{Treatment cost}

Since the relationship between treatment cost of reproductive failures and the length of calving interval depends highly on the reproductive disorder in the background, this expenditure is classified as auxiliary cost instead of loss due to extended calving interval. According to the results of Ózsvári (2004), this source of loss accounted for 12.4 USD per cow per year in Hungary. Numerous studies have dealt with the economic aspects of selective treatment so far. In this case the decision of treating the animal at all and the treatment used is based on the production parameters of the individual and the characteristics of the disease (severity, pathogen). Selective treatment was found to be economically beneficial only among certain farm characteristics (Leblanc, 2008).

\section{Economic aspects of insemination}

Optimal time of conception is one of the most important elements of reproductive management on dairy farms. In order to achieve this goal, the efficient heat detection is a key element. Heat detection efficiency is less, than $50 \%$ in the USA, which causes more than 300 million USD loss in dairy cattle industry (Meadows et al., 2008). As a consequence of the growing herd size, time available for heat detection becomes even less, furthermore, modern high-yielding cattle breeds show the signs of oestrus for a shorter period and less intensively. This change led to the invention of devices that support the farmer in oestrus detection. It is important to note that the realizable profit depends on the initial heat detection efficiency: higher profits can be realized if the initial efficiency is lower (Table 7).

Table 7. Profit related to improved heat detection efficiency

\begin{tabular}{|l|c|c|c|}
\hline \multicolumn{1}{|c|}{ Study } & $\begin{array}{c}\text { Efficiency at the } \\
\text { start (\%) }\end{array}$ & $\begin{array}{c}\text { Improved } \\
\text { efficiency (\%) }\end{array}$ & Profit/cow/year \\
\hline \multirow{2}{*}{ Pecsok et al., 1994 } & 20 & 30 & 83 USD \\
\cline { 2 - 4 } & 60 & 70 & 13 USD \\
\hline \multirow{2}{*}{$\begin{array}{l}\text { De Vries and Conlin, } \\
2003\end{array}$} & 35 & 45 & 27 USD \\
\cline { 2 - 4 } & 55 & 65 & 8 USD \\
\hline \multirow{2}{*}{ Inchaisri et al., 2010 } & 30 & 50 & 53.30 EUR \\
\cline { 2 - 4 } & 50 & 70 & 11.20 EUR \\
\hline
\end{tabular}

Source: Meadows et al. (2008); Inchaisri et al. (2010)

Another option for achieving better conception rate is introducing an oestrus synchronization program (e.g. Ovsynch) on the farm. Timed ovulation facilitates artificial insemination without heat observation. Its major advantage is that no extra 
Fodor, I. - Dunay, A. - Ózsvári, L.

labour is required, making it less sensitive to wages. Increased semen usage due to suboptimal conception rate was blamed for 14.8 USD additional expenditure per cow in Hungary according to the results of Ózsvári (2004).

\section{Materials and methods}

The data of 6,825 Holstein-Friesian cows from 8 large-scale Hungarian dairy herds were collected in 2011. All the farms included in this study used loose, deep-bedded system, diseased animals were kept separately and the herds were free from tuberculosis, brucellosis and bovine leucosis. Although the milking systems applied were different on every single farm, cows with mastitis were always milked separately. In all herds calvings were carried out in small groups, in straw-bedded calving stalls with loose system. In the examined period the average daily milk yield was $28.60 \mathrm{~kg}$ with $3.6 \%$ milk fat, $3.3 \%$ milk protein and $443,500 \mathrm{SCC} / \mathrm{ml}$. The average length of lactation was 360 days and the average calving interval reached 423 days. Milk samples were taken with sterile needles. SCC was determined with Fossomatic device by Animal Breeding Performance Testing Ltd..

The aim of our research was to quantify the average annual economic losses caused by mastitis and reproductive failures on Hungarian dairy cattle farms. Its basic logic is that by changing the value of production indexes it is possible to calculate how many additional returns would be derived from the absence of the disease in the herd.

\section{Calculation of losses due to mastitis}

Losses related to mastitis can be divided into 3 main categories: reduced milk receipts, costs of treatment and costs of premature disposal. The decreased milkproduction, the discarded milk and the lowered milk quality cause the reduced milk receipts. In the calculations we have to take into account that every $\mathrm{kg}$ of milk that is not produced means a saving of $0.5 \mathrm{~kg}$ milk concentrate (Ózsvári, 2004). Treatment costs consist of veterinary fees, drug costs and farmer's extra labour cost, however, the farms involved in our study employ their own veterinarian with fix salary, thus, making it a fixed cost, so we do not have to take the vet fees into account in our calculations using partial budget method. The extra labour of the farmer can also be regarded as a fixed cost, hence, this activity is also a part of the job of the farm employees with fix salary.

The individual SCC $(1000 / \mathrm{ml})$ and milk yield $(\mathrm{kg})$ data of the milk tests of 5,881 milking cows over the study period (01.01.2011-31.12.2011) were used in the calculations. Production data used to calculate annual losses caused by mastitis were obtained from the farms' logs. When quantifying the financial consequences of decreased milk yield, the cows having SCC more than $250,000 / \mathrm{ml}$ were regarded as ones with subclinical mastitis (consequently producing less milk), because above this threshold we can show the presence of udder pathogens in almost all the cases, while cows with SCC under $250,000 \mathrm{SCC} / \mathrm{ml}$ were regarded as healthy ones. According to the results of Raubertas and Shook (1982), Radostits et al. (1994) and Ózsvári et al. (2001, 2003a), who claimed that milk production loss can be identified above 100,000 
$\mathrm{SCC} / \mathrm{ml}$, irrespectively of being able to find pathogens in the milk, we compared the milk yield of the groups of cows producing above and under $100000 \mathrm{SCC} / \mathrm{ml}$, too. After calculating the average difference between the milk yield of healthy cows (control group) and that of cows with subclinical mastitis and in view of the selling prices of raw milk the losses due to reduced milk yield could be calculated.

The average difference between the daily milk yield of healthy cows and those with subclinical mastitis was calculated and then the annual decrease of milk production on herd-level was determined. Having known the selling price of raw milk and the cost of milk concentrate, the annual losses on cow herd and herd level was calculated, so the data of different farms with similar production system became comparable.

When calculating the economic effect of decreased milk quality, in Hungary we only have to quantify the reduced milk receipts due to elevated SCC, because in Hungary milk fat and milk protein content does not play a role in determining the milk price, so the decrease of fat $\%$ and protein $\%$, another result of mastitis, does not effect the farmers' receipts directly. The quality of the bulk tank milk met the requirements of the Hungarian food standards in all decades on all farms, so in our survey the decreased milk quality was not a factor effecting profitability.

When using udder infusions with antibiotics against mastitis, milk has to be discarded, which is also a source of economic loss. Knowing the number, type of udder infusions and the way of application, we could calculate the total withdrawal time (days) in the study period (01.01.2011-31.12.2011), taking the average daily milk yield and the selling price of raw milk in 2011 into account, the annual losses due to discarded milk became quantifiable.

Treatment costs were calculated by summing up the amount of the parenteral and udder infusion products used for mastitis treatment over the study period, and then these numbers were multiplied by the individual buying-up prices in 2011 .

Losses from premature disposal were calculated as the difference between the replacement cost of heifers and the slaughter value of culled cows.

\section{Calculation of losses due to reproductive disorders}

In the calculations, which were based on international methods, the fertility problems had three effects: longer calving interval, premature disposal and other costs. In the economic model the calving interval with highest yearly net return is defined as optimal, while the differences between that and every other calving interval indicate the losses as the decrease in income per cow per year (so-called obscured loss).

According to the international and Hungarian references the length of calving interval significantly influences two factors, namely, the net milk receipts (margin between gross milk receipts and feed costs) and calf sales. The number of lactations affects the milk production; hence, the cows were grouped by lactations in calculating the losses due to reduced net milk receipts. The number of calves born per year will decrease with longer calving intervals, therefore, the net income (margin between calf price and rearing costs) of calves born per year will diminish, as well. Considering calf sales only, the shortest calving interval is optimal. 
Fodor, I. - Dunay, A. - Ózsvári, L.

Other costs include the fertility treatment costs and expenses due to the increased number of inseminations compared to that assumed to be optimal. Experts consider 1.8 to be the optimal insemination index on average, which means 1.5 for heifers and 2 for cows (Radostits and Blood, 1985; Szenci, 1999; Ózsvári and Kerényi, 2004). Losses resulting from extra number of inseminations were calculated by dividing the optimal insemination index with the average insemination index on the farms and multiplying the result with the number of AI-s applied in 2011, so we got the optimal number of AI-s in 2011. Then by subtracting the optimal number of inseminations from the number of performed AI-s and multiplying the result with the average cost of an AI, the cost of extra inseminations became quantifiable.

Treatment costs include the veterinary fees, drug costs and extra labour of the farmer. However, the employees on the farm get a fix salary on an hourly basis, it is not needful to take the extra labour cost of the farmer into account. Drug costs were calculated as the multiplication of the number of all pharmaceutical products used for reproductive treatment and their buying prices in 2011. Losses due to early culling were calculated as the margin between the slaughter value of culled cow and the cost of replacement heifer, just like in the case of mastitis.

\section{Production data and prices}

In the calculations we used the average production and price data in 2011. In 2011 the mean buying-up price of raw milk was 32.23 eurocent, $1 \mathrm{~kg}$ of milk concentrate cost 27.27 eurocent on the farms involved in our study. Culled cows were sold at a price of 62.18 eurocent $/ \mathrm{kg}$ and the cows' mean weight was $566.5 \mathrm{~kg}$. Raising a replacement heifer up amounted to 1,224 EUR. 3,989 calves were born alive and calf mortality was $13.4 \%$. Calves weighed $103.5 \mathrm{~kg}$ on average when they were sold, their selling price was $2.71 \mathrm{EUR} / \mathrm{kg}$, while their rearing cost came up to $171.2 \mathrm{EUR}$. Insemination index was 3.15 in the studied population in 2011. The average insemination cost on the farms involved was 9.81 EUR.

\section{Results and discussion}

\section{Losses due to mastitis}

According to our assumption if the SCC of the milk increases above $250,000 / \mathrm{ml}$, the cow has subclinical mastitis and its milk yield reduces. In our calculations we compared the average milk yield of the cows above and under $250,000 \mathrm{SCC} / \mathrm{ml}$, however we also checked the difference above and under 100,000 SCC/ml (Table 8).

In the study $62.7 \%$ of the animals were considered healthy on average (under $250,000 \mathrm{SCC} / \mathrm{ml}$ ) and $37.3 \%$ of the cows produced milk above $250,000 \mathrm{SCC} / \mathrm{ml}$. Although it has to be noted that the large number of animals does not even mean a guarantee that the group of cows compared had the same production level before being diseased. But based on the milk test values of the compared groups of cows we can state that milk yield decreases as the SCC increases. Cows with subclinical mastitis produce $2.70 \mathrm{~kg}$ less milk daily on average as compared to the healthy ones (under $250,000 \mathrm{SCC} / \mathrm{ml})$. 
Table 8. Average daily milk yield decrease under and above $100,000 \mathrm{SCC} / \mathrm{ml}$ and 250,000 $\mathrm{SCC} / \mathrm{ml}$

\begin{tabular}{|l|c|c|c|}
\hline Individual SCC (1000/ml) & $\begin{array}{c}\text { Average milk yield } \\
\text { (kg/day) }\end{array}$ & Number of cows & $\begin{array}{c}\text { Daily milk yield } \\
\text { decrease (kg) }\end{array}$ \\
\hline$<\mathbf{1 0 0}$ & 31.40 & 2,193 & \multirow{2}{*}{4.50} \\
\hline$>\mathbf{1 0 0}$ & 26.90 & 3,688 & \multirow{2}{*}{2.70} \\
\hline$<\mathbf{2 5 0}$ & 29.50 & 3,688 & \\
\hline$>\mathbf{2 5 0}$ & 26.80 & 2,193 & \\
\hline
\end{tabular}

Source: own calculations

The average decrease in milk yield and losses resulting from subclinical mastitis are shown in Table 9. The losses due to reduced milk receipts are decreased by the value of milk concentrate not consumed (every $\mathrm{kg}$ of milk not produced means $0.5 \mathrm{~kg}$ milk concentrate not consumed by the cow). We calculated the difference between the milk production of the healthy cows and that of cows with subclinical mastitis and we also compared the milk yield of the cows with milk above $100,000 \mathrm{SCC} / \mathrm{ml}$ and that of cows with milk under 100,000 SCC/ml.

Table 9. Average milk yield decrease and losses related to subclinical mastitis

\begin{tabular}{|l|l|c|c|}
\hline & & $\begin{array}{c}\text { Above 100,000 } \\
\text { SCC/ml }\end{array}$ & $\begin{array}{c}\text { Above 250,000 } \\
\text { SCC/ml }\end{array}$ \\
\hline $\begin{array}{l}\text { Average decrease in } \\
\text { milk production }\end{array}$ & $\mathrm{kg} /$ milking cow/day & 4.50 & 2.70 \\
\cline { 2 - 4 } & $\mathrm{kg} / \mathrm{cow} /$ year & 888 & 317 \\
\hline $\begin{array}{l}\text { Savings in milk } \\
\text { concentrate }\end{array}$ & EUR/cow/year & 121 & 43.2 \\
\hline Losses & EUR/cow/year & 165 & 59 \\
\hline
\end{tabular}

Source: own calculations

Table 9 shows the average decrease in milk production owing to mastitis, which is more than $317,000 \mathrm{~kg}$ milk annually on a farm with 1,000 cows. If we examine the losses due to subclicinal mastitis with a $100,000 \mathrm{SCC} / \mathrm{ml}$ threshold, the decrease in milk production exceeds $888,000 \mathrm{~kg}$ milk in the same farm. If we take the savings of milk concentrate into consideration as a compensation factor, the losses from decreased milk yield due to subclinical mastitis amount up to 60 EUR per cow per year, which means nearly 60,000 EUR annually on a 1,000-cow farm!

In the farms involved in our study the withdrawal period because of the mastitis treatment was on average 5.37 days per cow annually. That means $178.2 \mathrm{~kg}$ discarded milk per cow-year, which causes a 49.5 EUR loss; on a 1,000-cow farm it almost reaches 49,500 EUR annually!

Table 10 shows that reduced milk receipts are 108 EUR per cow per year and in a farm with 1,000 cows the losses exceed 108,000 EUR yearly. Losses related to decreased milk production are responsible for the greatest share $(54.3 \%)$ of the reduced milk receipts. 
Fodor , I. - Dunay, A. - Ózsvári, L.

Table 10. Annual reduced milk receipts (EUR)

\begin{tabular}{|l|c|c|}
\hline \multirow{2}{*}{} & \multicolumn{2}{|c|}{ Annual reduced milk receipts (EUR) } \\
\cline { 2 - 3 } & per cow & in herd * \\
\hline Loss related to decreased milk production & 58.9 & 58,900 \\
\hline Loss related to discarded milk & 49.5 & 49,500 \\
\hline Total loss & $\mathbf{1 0 8 . 4}$ & $\mathbf{1 0 8 , 4 0 0}$ \\
\hline
\end{tabular}

* in a 1,000-cow herd

Source: own calculations

Drug costs related to mastitis resulted in 88,161 EUR annual costs on the farms studied in 2011. It means 12.9 EUR treatment cost per cow per year on the model farm with 1,000 cows it exceeds 12,900 EUR yearly. Premature disposal due to mastitis costs 39.1 EUR per cow per year on average, in a 1,000-cow farm this expenditure exceeds 39,000 EUR.

Table 11. Annual loss due to mastitis (EUR)

\begin{tabular}{|l|c|c|}
\hline \multirow{2}{*}{} & \multicolumn{2}{|c|}{ Annual loss (EUR) } \\
\cline { 2 - 3 } & per cow & in herd * \\
\hline Reduced milk receipts & 108.4 & 108,400 \\
\hline Treatment costs & 12.9 & 12,900 \\
\hline Cost of premature disposal & 39.1 & 39,100 \\
\hline Total & $\mathbf{1 6 0 . 4}$ & $\mathbf{1 6 0 , 4 0 0}$ \\
\hline
\end{tabular}

* in a 1,000-cow herd

Source: own calculations

In the herds examined the average annual losses owing to mastitis exceeded 160,000 EUR (Table 11). Annual losses amounted to 160.4 EUR per cow on average.

\section{Economic losses due to reproductive disorders}

Table 12 and 13 show the lactational and annual milk yields categorized by the lactation number and the calving interval.

Table 12. Average lactational milk yield per cow (litres of milk/cow)

\begin{tabular}{|l|r|c|c|r|r|r|r|r|}
\hline \multicolumn{2}{|c|}{ Calving interval (months) } & $\mathbf{1 1}$ & $\mathbf{1 2}$ & $\mathbf{1 3}$ & $\mathbf{1 4}$ & $\mathbf{1 5}$ & $\mathbf{1 6}$ & $\mathbf{1 7 - 1 8}$ \\
\hline & $\mathbf{n}$ & 381 & 437 & 347 & 284 & 208 & 195 & \multicolumn{1}{c|}{485} \\
\hline 1. lactation & 1,081 & 8,396 & 8,789 & 9,352 & 9,805 & 10,368 & 10,275 & 10,423 \\
\hline 2. lactation & 683 & 9,699 & 9,865 & 10,465 & 10,327 & 10,668 & 10,264 & 10,761 \\
\hline 3. lactation & 331 & 8,902 & 9,071 & 9,604 & 10,130 & 9,855 & 10,355 & 10,169 \\
\hline 4-9. lactation & 242 & 8,247 & 8,255 & 8,892 & 8,438 & 9,367 & 11,246 & 9,084 \\
\hline $\begin{array}{l}\text { Average milk yield } \\
\text { per cow }\end{array}$ & 2,337 & 8,782 & 9,067 & 9,656 & 9,855 & 10,266 & 10,365 & 10,337 \\
\hline
\end{tabular}

n: number of cows

Source: own calculations 
Table 13. Average annual milk yield per cow (litres of milk/cow/year)

\begin{tabular}{|l|r|r|c|c|c|c|c|c|}
\hline \multicolumn{2}{|c|}{ Calving interval (months) } & \multicolumn{1}{c|}{$\mathbf{1 1}$} & $\mathbf{1 2}$ & $\mathbf{1 3}$ & $\mathbf{1 4}$ & $\mathbf{1 5}$ & $\mathbf{1 6}$ & $\mathbf{1 7 - 1 8}$ \\
\hline & $\mathbf{n}$ & \multicolumn{1}{c|}{381} & \multicolumn{1}{c|}{437} & 347 & 284 & 208 & 195 & \multicolumn{1}{c|}{485} \\
\hline 1. lactation & 1,081 & 9,148 & 8,789 & 8,642 & 8,421 & 8,317 & 7,733 & 7,178 \\
\hline 2. lactation & 683 & 10,568 & 9,865 & 9,670 & 8,869 & 8,558 & 7,724 & 7,411 \\
\hline 3. lactation & 331 & 9,699 & 9,071 & 8,875 & 8,700 & 7,906 & 7,793 & 7,003 \\
\hline 4-9. lactation & 242 & 8,986 & 8,255 & 8,217 & 7,247 & 7,514 & 8,463 & 6,256 \\
\hline $\begin{array}{l}\text { Average milk } \\
\text { yield per cow }\end{array}$ & 2,337 & 9,568 & 9,067 & 8,923 & 8,464 & 8,235 & 7,800 & 7,119 \\
\hline
\end{tabular}

n: number of cows

Source: own calculations

Our results confirm the literature data stating that the milk yield is lower for firstcalf heifers in comparison to cows with more calves and milk production per cow per year decreases as calving interval increases.

Table 14 shows that the highest net milk receipts (milk receipts over feed costs) per cow is reached at an 11-month-long ( $<350$ days) calving interval in the herds studied. The average net milk receipts were 1,105 EUR per cow in 2011.

Table 14. Net milk receipts (milk receipts over feed costs) per cow per year for different calving intervals (EUR/cow/year)

\begin{tabular}{|l|r|c|c|c|c|c|c|c|}
\hline \multicolumn{2}{|l|}{ Calving interval (months) } & $\mathbf{1 1}$ & $\mathbf{1 2}$ & $\mathbf{1 3}$ & $\mathbf{1 4}$ & $\mathbf{1 5}$ & $\mathbf{1 6}$ & $\mathbf{1 7 - 1 8}$ \\
\hline & $\mathbf{n}$ & 381 & 437 & 347 & 284 & 208 & 195 & 485 \\
\hline 1. lactation & 1,081 & $1,193.3$ & $1,146.5$ & $1,127.2$ & $1,098.4$ & $1,084.9$ & $1,008.7$ & 936.3 \\
\hline 2. lactation & 683 & $1,378.5$ & $1,286.8$ & $1,261.4$ & $1,156.9$ & $1,116.3$ & $1,007.6$ & 966.7 \\
\hline 3. lactation & 331 & $1,265.2$ & $1,183.2$ & $1,157.6$ & $1,134.8$ & $1,031.2$ & $1,016.5$ & 913.5 \\
\hline 4-9. lactation & 242 & $1,172.1$ & $1,076.8$ & $1,071.8$ & 945.3 & 980.2 & $1,104.0$ & 816.0 \\
\hline $\begin{array}{l}\text { Average net milk } \\
\text { price income per cow }\end{array}$ & 2,337 & $1,248.1$ & $1,182.7$ & $1,163.9$ & 1,104 & $1,074.2$ & $1,017.5$ & 928.6 \\
\hline
\end{tabular}

$\mathrm{n}$ : number of cows

Source: own calculations

Table 15 shows the annual net return resulting from milk and calves and the losses calculated. Increased calving interval goes hand in hand with lesser calves sold. Annual net return exceeded 1,180 EUR per cow. The calving interval with highest net return is set at zero.

Taking both the net milk receipts and calf sales into account, the economically optimal calving interval is 11 months $(<350$ days) on average in the population surveyed, as well as, in each lactation the shortest calving interval is optimal. Average loss per cow per day shows the loss per each extra (open) day compared to the optimal calving interval. An average cow with 14-month-long calving interval produces 1.82 EUR loss per open day. Average daily loss per cow varies between 1.64-2.44 EUR according to the different length of calving intervals and reaches its maximum at 
Fodor , I. - Dunay, A. - Ózsvári, L.

12-month-long interval: 2.44 EUR. The average cost of an open day was 1.59 EUR in 2011. Longer calving interval resulted in 161 EUR loss per cow per year in 2011 based on the data obtained from 2,337 cows with an average calving interval of 423 days.

Table 15. Average net return and losses per cow (EUR/cow/year)

\begin{tabular}{|c|c|c|c|c|c|c|c|c|}
\hline \multicolumn{2}{|c|}{ Calving interval (months) } & 11 & 12 & 13 & 14 & 15 & 16 & $17-18$ \\
\hline & $\mathbf{n}$ & 381 & 437 & 347 & 284 & 208 & 195 & 485 \\
\hline 1. lactation & 1,081 & $1,286.9$ & $1,232.4$ & $1,206.7$ & $1,172.2$ & $1,153.9$ & $1,073.4$ & 995.5 \\
\hline 2. lactation & 683 & $1,472.1$ & $1,372.8$ & $1,340.8$ & $1,230.7$ & $1,185.3$ & $1,072.3$ & $1,025.9$ \\
\hline 3. lactation & 331 & $1,358.8$ & $1,269.2$ & $1,237.1$ & $1,208.7$ & $1,100.2$ & $1,081.2$ & 972.7 \\
\hline 4-9. lactation & 242 & $1,265.7$ & $1,162.8$ & $1,151.2$ & $1,019.1$ & $1,049.1$ & $1,168.7$ & 875.2 \\
\hline $\begin{array}{l}\text { Average income } \\
\text { per cow }\end{array}$ & \multirow{2}{*}{2,337} & $1,341.8$ & $1,268.7$ & $1,243.3$ & $1,177.8$ & $1,143.2$ & $1,082.2$ & 987.8 \\
\hline $\begin{array}{l}\text { Average loss per } \\
\text { cow }\end{array}$ & & 0 & 73.1 & 98.5 & 163.9 & 198.6 & 259.6 & 354 \\
\hline \multicolumn{2}{|c|}{$\begin{array}{r}\text { Average daily loss } \\
\text { (EUR/cow) }\end{array}$} & 0 & 2.4 & 1.6 & 1.8 & 1.7 & 1.7 & 1.8 \\
\hline
\end{tabular}

n: number of cows

Source: own calculations

Premature disposal related to reproductive reasons caused 30.5 EUR loss per cow per year on average. Treatment costs due to reduced fertility resulted in 16.9 EUR loss per cow annually, while the cost of increased number of inseminations was 18.7 EUR per cow per year on average in 2011.

Total costs related to reproductive failures exceeded 227 EUR per cow yearly (Table 16)! Longer calving interval caused the majority of this loss $(70.9 \%, 161$ EUR). Premature disposal owing to reproductive disorders also had large economic impact, causing 13.4\% (30.5 EUR) of the total loss. Treatment cost brought about 16.9 EUR $(7.4 \%)$, while increased number of services per cow was responsible for $8 \%(18.7$ EUR) of the total expenditures.

Table 16. Annual losses related to reproductive disorders per cow

\begin{tabular}{|l|c|c|}
\hline \multirow{2}{*}{ Source of loss } & \multicolumn{2}{|c|}{ Annual loss per cow } \\
\cline { 2 - 3 } & EUR & \% \\
\hline Longer calving interval & 161.0 & 70.89 \\
\hline Premature disposal & 30.5 & 13.43 \\
\hline Treatment cost & 16.9 & 7.44 \\
\hline Increased number of inseminations & 18.7 & 8.24 \\
\hline Total & $\mathbf{2 2 7 . 1}$ & $\mathbf{1 0 0 . 0 0}$ \\
\hline
\end{tabular}

Source: own calculations 


\section{Conclusions}

In regards 6,825 cows involved in our study three-quarter of the economic losses were so-called obscured losses (decreased income). In practice, they are usually underestimated by the farmers, therefore, less attention is paid to avoid these losses. Considering the average production level of the population examined, the optimal calving interval is 11 months ( $<350$ days) that can be achievable by shortening the average calving interval by 70 days, which is impossible and probably not beneficial in practice. However, shortening the calving interval with 10 days in the population surveyed would bring about a higher profit with several ten thousands euros and it can be achieved in the short run. Based on these data it can be concluded that the farmers (and of course, veterinarians) should pay more attention to the obscured production losses, namely, improving udder health and milking hygiene (thus minimizing the decrease in milk production owing to subclinical mastitis), as well as, improving reproductive management, particularly by shortening the calving interval, since these factors have the largest economic impact on the profitability of dairy farms.

\section{References}

1. Animal Breeding Performance Testing Ltd. (2011): Partner-tájékoztató Hírlevél, Gödöllö, 4: 8 .

2. Bar, D. - Tauer, L. W. - Bennett, G. - González, R. N. - Hertl, J. A. - Schukken, Y. H. Schulte H. F. - Welcome, F. L. - Gröhn, Y. T. (2008): The Costs of Generic Clinical Mastitis in Dairy Cows as Estimated by Using Dynamic Programming. J.Dairy Sci. 91:2205-2214.

3. Blosser, T. H. (1979): Economic Losses from and the National Research Program on Mastitis in the United States. J.Dairy Sci. 62:119-127.

4. Cha, E. - Bar, D. - Hertl, J. A. - Tauer, L. W. - Bennett, G. - González, R. N. - Schukken, Y. H. - Welcome, F. L. - Gröhn, Y. T. (2011): The cost and management of different types of clinical mastitis in dairy cows estimated by dynamic programming. J. Dairy Sci. 94: 4476-4487.

5. De Vries, A. (2006): Economic Value of Pregnancy in Dairy Cattle. J. Dairy Sci. 89: 38763885.

6. Dobbins, C. N. (1977): Mastitis losses. J. Amer. Vet. Med. Ass. 170: 1129.

7. Goshen, T. - Shpigel, N. Y. (2006): Evaluation of intrauterine antibiotic treatment of clinical metritis and retained foetal membranes in dairy cows. Theriogenology 66: 22102218.

8. Hagnestam-Nielsen, C. - Emanuelson, U. - Berglund, B. - Strandberg, E. (2009): Relationship between somatic cell count and milk yield in different stages of lactation. J. Dairy Sci. 92: 3124-3133.

9. Halasa, T. - Nielen, M. - De Roos, A. P. W. - Van Hoorne, R. - De Jong, G. - Lam, T. J. G. M. - Van Werven, T. - Hogeveen, H. (2009): Production loss due to new subclinical mastitis in Dutch dairy cows estimated with a test-day model. J. Dairy Sci. 92:599-606.

10. Hazlett, M. J. - Little, P. B. - Maxie, M. G. - Barnum, D. A. (1984): Fatal Mastitis of dairy cows. Can. J. Comp. Med. 48:125-129.

11. Huijps, K. - Hogeveen, H. - Lam, T. J. G. M. - Oude Lansink, A. G. J. M. (2010): Costs and efficacy of management measures to improve udder health on Dutch dairy farms. J. Dairy Sci. 93:115-124. 
Fodor, I. - Dunay, A. - Ózsvári, L.

12. Illés, B. Cs. (1998): Az állattenyésztési ágazatok versenyképességének értékelése, figyelemmel a várható mezőgazdasági struktúraváltozásokra. (Evaluation of competitiveness of the livestock sector, considering the structural changes of the Hungarian agriculture) Tudományos Közlemények. GATE, Gazdaság- és Társadalomtudományi Kar, No. 1., Gödöllö, pp. 187-193.

13. Inchaisri, C. - Jorritsma, R. - Vos, P. L. A. M. - Van Der Weijden, G. C. - Hogeveen, H. (2010): Economic consequences of reproductive performance in dairy cattle. Theriogenology 74: 835-846.

14. Leblanc, S. J. (2008): Postpartum uterine disease and dairy herd reproductive performance: A review. The Veterinary Journal 176: 102-114.

15. Leblanc, S. J.- Lissemore, K. D.- Kelton, D. F.- Duffield, T. F.- Leslie, K. E. (2006): Major Advances in Disease Prevention in Dairy Cattle. J. Dairy Sci. 89: 1267-1279.

16. McNab, W.B.- Meek, A. H. (1991): A benefit-cost analysis of dry-cow mastitis therapy in dairy cattle in Ontario. Can. Vet. J. 32: 347-353.

17. Meadows, C. - Rajala-Schultz, P. J. - Frazer, G. S. (2005): A Spreadsheet-Based Model Demonstrating the Nonuniform Economic Effects of Varying Reproductive Performance in Ohio Dairy Herds. J. Dairy Sci. 88: 1244-1254.

18. Meadows, C. - Rajala-Schultz, P. J. - Frazer, G. S. - Meiring, R. W.- Hoblet, K. H. (2008): Evaluation of a contract breeding management program in Ohio dairy herds: Test day summary and economic measures. Ani. Repro. Sci. 104: 189-200.

19. Mee, J. F. (2007): The role of the veterinarian in bovine fertility management on modern dairy farms. Theriogenology $68 \mathrm{~S}: \mathrm{S} 257-\mathrm{S} 265$.

20. Olynk, N. J - Wolf, C. A. (2008): Economic Analysis of Reproductive Management Strategies on US Commercial Dairy Farms. J. Dairy Sci. 91: 4082-4091.

21. Østergaard, S. - Chagunda, M. G. G. - Friggens, N. C. - Bennedsgaard, T. W. - Klaas, I. C. (2005): A Stochastic Model Simulating Pathogen-Specific Mastitis Control in a Dairy Herd. J. Dairy Sci. 88: 4243-4257.

22. Ózsvári, L. - Antal, L. - Illés, B. Cs. - Bartyik, J.- Szenci, O. (2001): Quantification of losses resulting from decrease in milk production caused by subclinical mastitis on the basis of individual somatic cell count (in Hungarian). Hungarian Veterinary Journal, 123: (10), pp. 600-604.

23. Ózsvári, L. - György, K. - Illés, B. Cs. - Bíró, O. (2003a): Quantification of economic losses caused by mastitis on a large-scale Holstein-Friesian dairy farm (in Hungarian). Hungarian Veterinary Journal, 125:(5), pp. 273-279.

24. Ózsvári, L. - Taradan, S. - Illés, B. Cs. - Bíró, O. (2003b): Tejtermelő szarvasmarha telepek termelési mutatóinak és gyógyszerköltségének összehasonlító vizsgálata: Comparative studies of production data and drug costs of dairy cattle holdings. Magyar Állatorvosok Lapja (Hungarian Veterinary Journal), 125:(9), pp. 522-531.

25. Ózsvári, L. - Kerényi, J. (2004): Quantification of losses due to reproductive disorders on a large-scale Holstein-Friesian dairy farm (in Hungarian). Hungarian Veterinary Journal, 126. 523-531.

26. Ózsvári, L. - Tóth, F. - Gábor, Gy. - Szenci, O. (2007): The economic importance of reproductive management in dairy herds. Rev. Rom. Med. Vet. 17: 37-46.

27. Ózsvári, L. (2004): Economic analysis of decisions with respect to dairy cow health management (in Hungarian with English thesis). Doctoral (PhD) dissertation. SZIU-FVS, Gödöllö, $145 \mathrm{p}$.

28. Radostits, O. M. - Blood, D. C. (1985): Herd health. London: W. B. Saunders Co., 154.

29. Radostits, O. M. - Leslie, K. E. - Fetrow, J. (1994): Herd Health. Food Animal Production Medicine. 2nd edition. Saunders Company, London: W.B. 603. 
30. Rafai, P. - Brydl, E. - Nagy, Gy. (2003): A sertés-, a szarvasmarha- és a házityúktartás higiéniája és állomány-egészségtana. Budapest: Agroinform Kiadó, 274-298.

31. Raubertas, R. P. - Shook, G. E. (1982): Relationship between lactation measures of somatic cell concentration and milk yield. J. Dairy Sci. 65: 419-425.

32. Seegers, H. - Fourichon, C. - Beaudeau, F. (2003): Production effects related to mastitis and mastitis economics in dairy cattle herds. Vet. Res. 34: 475-491.

33. Steeneveld, W. - Van Werven, T. - Barkema, H. W. - Hogeveen, H. (2011): Cow-specific treatment of clinical mastitis: An economic approach. J.Dairy Sci. 94:174-188.

34. Swinkels, J. M. - Hogeveen, H. - Zadoks, R. N. (2005): A Partial Budget Model to Estimate Economic Benefits of Lactational Treatment of Subclinical Staphylococcus aureus Mastitis. J.Dairy Sci. 88: 4273-4287.

35. Szenci, O. (1999): Az ellés utáni időszak szaporodásbiológiai gondozása tejhasznú tehenészetekben. Magyar Állatorvosok Lapja 121: 78-81.

36. Valeeva, N. I. - Lam, T. J. G. M. - Hogeveen, H. (2007): Motivation of Dairy Farms to Improve Mastitis Management. J. Dairy Sci. 90: 4466-4477.

37. Vucseta, Á. (2002): A legmagasabb termelésű tehenészeti telepek termelési adatai, 2001. Mikrohíradó (A Mikro Trade Kft. takarmányozási értesítője). 1-6.

38. Wolfová, M. - Stipková, M. - Wolf, J. (2006): Incidence and economics of clinical mastitis in five Holstein herds in the Czech Republic. Prev. Vet. Med. 77: 48-64.

39. Yalcin, C.- Stott, A. W.- Logue, D. N.- Gunn, J. (1999): The economic impact of mastitiscontrol procedures used in Scottish dairy herds with high bulk-tank somatic cell counts. Prev.Vet.Med. 41: 135-149. 